\title{
Decontamination Strategies for a Few Potentially Pathogenic and Food Spoilage Causing, Antibiotic-Resistant Bacteria Isolated From Commonly Used Food Garnishes
}

\author{
Payel Sarkar*, R. Divya, S. Sumanashree and K. Swathi \\ Department of Microbiology, Ramaiah College of Arts, Science and Commerce, \\ MSR Nagar, MSRIT Post, Bangalore- 560054, Karnataka, India \\ *Corresponding author
}

\section{A B S T R A C T}

\begin{tabular}{|l|}
\hline K e y w o r d s \\
Food garnishes, \\
Antibiotic \\
resistance, Food \\
spoilage, Food- \\
borne infection, \\
Decontamination. \\
\hline Article Info \\
\hline Accepted: \\
22 January 2017 \\
Available Online: \\
10 February 2017 \\
\hline
\end{tabular}

Keywords

Food garnishes, Antibiotic Article Info Accepted: 22 January 2017 Available Online:

\section{Introduction}

Garnishes can be defined as substances which are used to decorate food dishes and beverages. Garnishes can be broadly classified into edible and non-edible garnishes (Lynch, 1987). Edible garnishes are those which can be consumed along with the food to which it is added, for example, coriander on Indian curry dishes. Non-edible garnishes aid in the visual impact of the food and they do not impart any flavour to the food. These are usually discarded by the consumers, example: cocktails can be garnished with plastic cocktail umbrellas. Edible garnishes make food items look more appealing, complement the food, add nutritional value, colour balance and enhance the taste of the food. Some of the edible garnishes include cloves, cardamom, curry leaves, chilli pepper, kasuri methi, mint, pepper corns, oregano powder, coriander leaves, spring onions, paprika powder, tomato, pomegranate, coconut, dry fruits, dry chilli, grapes, honey, lime etc. Along with these garnishes many other food garnishes are used worldwide in various food delicacies. Here, our study is limited only to edible or food garnishes. 
Besides the numerous beneficial aspects of food garnishes, there are also a few drawbacks. The drawback of food garnishes which is of concern to a microbiologist is the fact that food garnishes are added to a dish uncooked and thus, potentially capable of being vectors of microorganisms and cause food spoilage and food poisoning (Campbell, 2001; Elviss, 2009). A lot of work has been done on uncooked vegetables, spices and nuts (Ali, 2014; Andleeb, 2013; Banerjee, 2004; Ghosh, 2007; Khan, 2012; Nipa, 2011; Roy, 2007; Sago, 2003; Schaffner, 1967; Shrivastava, 2014). However, not much work has been done on garnishes so far, except parsley and mint (Hsu, 2010; Naimi, 2003; $\mathrm{Wu}, 2000$ ), even though they have been a part of our daily food. Methods to improve the microbial quality of these food garnishes have also been minimally analyzed. Hence, having a better knowledge on food garnishes, the possible microorganisms they harbor, their types, and in turn the spoilage and poisoning they cause is essential. Thus, the scope of research on garnish-borne food spoilage and food poisoning causing microorganism and on measures to control them is enormous. We have restricted our studies to bacterial food pathogens. Bacteria related food poisoning is the most common. More than 90 percent of the cases of food poisoning each year are caused by Staphylococcus aureus, Salmonella, Clostridium perfringens, Campylobacter, Listeria monocytogenes, Vibrio parahaemolyticus, Bacillus cereus, and Entero-pathogenic Escherichia etc (Zhuang, 1995).

In the event of contracting food poisoning from contaminated food items, antibiotics would be the best bet for treatment of such diseases. However, the biggest challenge in antibiotic treatment is the development of antibiotic resistance in pathogenic microorganisms. Infections caused by resistant microorganisms often fail to respond to the standard treatment, resulting in prolonged illness, higher health care expenditures, and a greater risk of death. Antimicrobial resistance has been recognized as an important global health problem over the past few decades (Kang, 2013; WHO, 2001). Hence, antibiotic sensitivity test must be carried out in order to choose an antibiotic against specific bacteria and to determine whether that particular bacteria is resistant, susceptible or sensitive to the antibiotic, which further helps to carry out the treatment to an infected patient.

Antibiotic sensitivity tests help to determine whether the microorganism in question is susceptible to a particular antibiotic or not. In case food spoilage or food poisoning causing microorganisms are found to be resistant to a wide range of antibiotics, attempt should be made to reduce the chance of such contamination in the first place, especially for food garnishes which remain uncooked. This can be done by use of decontaminants to get rid of or to reduce the number of microorganisms present on garnishes before application on to food items. Apart from the general decontamination methods, for example heat, liquid disinfectants, and radiation, there are few home remedies, which can be practiced (Bowles, 1995; Bowles, 1998; Bradley, 2011; Chantaysakorn, 2000; Delaquis, 1995; Frederick, 1994; Fukao, 2000; Tokuoka, 1994, Tzortzakis, 2010). These home remedies include various organic acid, plant extracts etc. The advantage of using these home remedies as decontaminants is that they are safer, cheaper and ecofriendly.

The objective of this study was to analyze some of the common food garnishes from different sources from which possible food pathogens and food spoilage causing bacteria can be isolated and studied. Following characterization of the isolated bacteria, effort 
was also made to study the antibiotic resistance of the isolated bacteria, in order to evaluate the chance of success of antibiotic therapy in case of an incidence of the disease. We also tested the use of different home remedies, which could be employed at low cost to decontaminate the uncooked food garnishes before their application onto food items.

\section{Materials and Methods}

\section{Sample collection}

A total of 100 random samples of 16 different kinds of food garnishes (Table 1) was purchased from different retail outlets from in and around Bangalore, India. Approximately $50-100 \mathrm{~g}$ of unpacked garnish samples were collected in sterile aluminum foil pouches. Samples were transported to the laboratory and analyzed as soon as possible.

\section{Isolation}

Different media (BPA: Baird Parker agar (HiMedia - M043), BSA: bile salt agar (HiMedia - M027), EMBA: eosin methylene blue agar (HiMedia - M317), SSA: Salmonella-Shigella agar media (Micro master - DM236), TCBSA: thiosulfatecitrate-bile salts-sucrose agar (Micro master DM253)) were used for the isolation of bacteria from the samples. The Petri plates were labelled and six divisions were made on each plate. On each Petri plate six different samples of each of the food garnishes were placed. Sterile forceps and needle were used for taking small pieces of food garnishes and plating them on to the media plates. The plates were incubated overnight at $37^{\circ} \mathrm{C}$. Microscopic examination and biochemical characterization of the isolates were carried on the basis of characters given in the Bergey's manual (2012): Gram staining, oxidase test, catalase test, lactose fermentation test, glucose fermentation test, mannitol salt test, indole test, citrate utilization test, Voges-Proskauer test, $\mathrm{H}_{2} \mathrm{~S}$ production, Motility test by hanging drop method and $1 \%$ Sodium requirement for growth.

\section{Antibiotic sensitivity test}

Antibiotic sensitivity test was performed for the following probable bacteria: Citrobacter diversus, Escherichia coli, Klebsiella, Staphylococcus aureus, Micrococcus.variens, Pseudomonas, Shigella, Vibrio. The commercial antibiotic discs used were: Ampicillin (HiMedia - SD002 - 10mcg/disc), Ampicillin cloxacillin (HiMedia - SD113 10mcg/disc), Amoxycillin (HiMedia - SD00110mcg/disc), Bacitracin (HiMedia - SD003 10units/disc), Kanamycin (HiMedia - SD223 - 5mcg/disc), Penicillin (HiMedia - SD028 10units/disc), Streptomycin (HiMedia SD031-1VL - 10mcg/disc), Tetracycline (HiMedia -D037 - 30mcg/disc). The test organism was picked using sterile cotton swab and swabbed onto sterilized and solidified Nutrient Agar medium (Micro master - DM180) in Petri plates. Under aseptic conditions the antibiotic discs were placed on the agar plates and incubated for $24 \mathrm{~h}$ at $37^{\circ} \mathrm{C}$. After the completion of incubation, the plates were observed for zone of inhibition. The diameter of the zone of inhibition was measured and the results were noted.

\section{Decontaminant test}

The nutrient agar and Luria Bertani (LB) agar (HiMedia M1245 and MB053) media were prepared and autoclaved. Discs were made out of filter paper and sterilized. Decontaminants i.e., $5 \%$ baking soda, $5 \%$ salt in distilled water, commercial fruit and vegetable wash (Ingredients: sorbitol ester, purified aqua), vinegar (Glacial acetic acid 
4\%- commercially obtained), baking soda+salt (5\% salt and 5\% baking soda in distilled water), baking soda+vinegar $(5 \%$ baking soda in vinegar), salt+vinegar (5\% salt in vinegar), vinegar+salt+baking soda (5\% salt and 5\% baking soda in vinegar) were prepared and autoclaved except the commercial wash, which was used as obtained. The autoclaved nutrient agar and LB agar media was poured into the plates. The test organism was picked using sterile cotton swab and swabbed on to the agar medium (Citrobacter, Escherichia coli, Klebsiella and Micrococcus were swabbed onto LB plates and Pseudomonas, Shigella, Staphylococcus aureus and Vibrio were swabbed onto NA plates. The discs were immersed in the decontaminants and were placed on the media plates using sterile forceps. One disc was kept as control, which was not immersed in any of the decontaminants. The plates were incubated for $24-48 \mathrm{~h}$ at $37^{\circ} \mathrm{C}$. After the completion of incubation, the plates were observed for zone of inhibition. The diameter of the zone of inhibition was measured and the results were noted.

\section{Results and Discussion}

Most food garnishes studied were found to harbour potentially pathogenic and/or spoilage causing bacteria during initial screening

Initial screening was done to check whether the test food garnishes contain any potentially pathogenic and spoilage causing bacteria. Sixteen food garnishes were initially considered for screening. A total of hundred random samples of these sixteen food garnishes (Table 1) were analyzed on different media. After incubation, most of the food garnishes yielded colonies on the different media analyzed. Out of the sixteen food garnishes analyzed, four food garnishes, i.e. black pepper, dry chilli pepper, honey and kasuri methi, did not show any growth or showed only minimal growth (Figure 1) and were therefore eliminated from further studies. The observed result for these four garnishes could be due to the fact that these four garnishes have also been documented as spices and condiments with antimicrobial properties (Israili, 2014; Keskin, 2011; Reddy, 2004; Yadav, 2014). For each of the twelve remaining food garnishes, colonies with different characteristics were chosen for further characterization.

Eight different potentially pathogenic and/or spoilage causing bacteria were isolated from twelve different types of food garnishes

The twelve food garnishes selected following the initial screening (Figure 1) were used for the isolation and characterization of susceptible pathogenic bacteria on different media. Media play a major role in isolating the organisms because several selective and differential media are there, which could be helpful in selecting a particular organisms i.e., E.coli, Shigella, Vibrio etc. or in differentiating between two organisms. We used several media: Baird Parker Agar, Eosin Methylene Blue agar, Nutrient agar, TCBS agar, Salmonella Shigella Agar in the present study. The isolated colonies were characterized according to the Bergey's Manual (2012) using microscopic staining and biochemical tests. Based on these tests, eight bacteria were tentatively identified (Table 2)- Citrobacter diversus, Escherichia coli, Klebsiella oxytoca, Micrococcus varians, Pseudomonas, Shigella, Staphylococcus aureus and Vibrio. The tentative designation is due to the fact that these organisms were characterized only on the basis of phenotypic characteristics (staining and biochemical tests) (Bergey's manual, 2012) and not by genotypic methods including $16 \mathrm{~S}$ rRNA 
analysis (Clarridge, 2004). Genotypic analysis was not included because the objective of the study was to aim at eliminating any potentially pathogenic or food spoilage causing bacteria that may be present on food garnishes rather than target and eliminate specific bacteria. All the isolated organisms are known to cause food poisoning and/or food spoilage (Adams, 2000; Arslan, 2011, Doran, 1999; Drake, 2007; Frost, 1995; Lund, 1993; Sabota, 1998; Silbernagel, 2001; Wogu, 2014).

Bacteria isolated from the food garnishes in this study were resistant to one or more antibiotics

To determine whether the isolated bacteria were resistant to any antibiotics, antibiotic sensitivity tests were performed using the disc diffusion method (Serrano, 2004) against eight different antibiotics. The zones of inhibition were measured and the results were interpreted (Table 3) as R (resistant to the particular antibiotic), $\mathrm{S}$ (sensitive to the particular antibiotic) or I (intermediate sensitivity to the particular antibiotic). It was found that all eight isolated bacteria were resistant to at least one of the tested antibiotics (Figure 2). Citrobacter diversus was found to be resistant to all tested antibiotics except Kanamycin and Tetracycline. Escherichia coli was found to be resistant to Ampicillin-cloxacillin, Amoxycillin, Bacitracin, Penicillin and Tetracycline. Klebsiella oxytoca was found to be resistant to all tested antibiotics and only sensitive to Streptomycin. Micrococcus varians was found to be resistant to Ampicillin, Ampicillin-cloxacillin, Kanamycin, Penicillin and Streptomycin. Pseudomonas was found to be resistant to Ampicillin, Ampicillin-Cloxacillin, Amoxycillin, Bacitracin and Penicillin. Shigella was found to be resistant all tested antibiotics except Kanamycin. Staphylococcus aureus was the only organism that was found to be resistant to only one of the tested antibiotics. Vibrio was resistant to Ampicillin, Bacitracin, Kanamycin, Penicillin and Tetracycline and sensitive to AmpicillinCloxacillin, Amoxycillin and Streptomycin. Thus, the isolated bacteria from garnishes were found to be resistant to one or more antibiotics, which implies that these bacteria have developed resistance to the antibiotics and therefore, would be ineffective for therapeutic purposes. Antibiotic resistance by pathogenic bacteria is showing to be a threat to human and animal community and our results only corroborate our drift towards a post-antibiotic era (Alanis, 2005). Hence, there is a growing need to reduce the chance of contamination by these bacteria beforehand.

Vinegar and 5\% salt in vinegar were found to be the most effective decontaminant for bacteria isolated from food garnishes used in this study

In an attempt to reduce chances of contamination of food items following addition of food garnishes, several homeremedies were tested for their role as decontaminants. The decontaminants used were baking soda, salt water, vinegar, commercially available fruit and vegetable wash and different combinations of two or more of these (Table 4). The test method was similar to the disc diffusion method used for the antibiotic sensitivity assays.

The results were interpreted by the measured zones of inhibition (Figure 3). It was observed that most of the tested decontaminants were effective against Citrobacter diversus. For Escherichia coli, vinegar, 5\% baking soda in vinegar and 5\% salt in vinegar were effective. For Klebsiella oxytoca, only vinegar and salt water were effective. Vinegar, 5\% baking soda in vinegar and 5\% salt in vinegar produced measurable zones of inhibition for Micrococcus varians. 
Table.1 Selected food garnishes for screening and subsequent isolation along with their scientific names, total number of samples and their results on each medium in $\%$.

\begin{tabular}{|c|c|c|c|c|c|c|c|c|}
\hline \multirow{2}{*}{$\begin{array}{l}\text { Sl. } \\
\text { No. }\end{array}$} & \multirow[b]{2}{*}{ Food Garnish } & \multirow{2}{*}{$\begin{array}{l}\text { Scientific } \\
\text { Name }\end{array}$} & \multirow{2}{*}{$\begin{array}{c}\text { Total } \\
\text { No. } \\
\text { of } \\
\text { Samples } \\
\end{array}$} & \multicolumn{5}{|c|}{ \% Positive on Each Medium } \\
\hline & & & & BPA & BSA & EMBA & SSA & TCBSA \\
\hline 1 & Black pepper & Piper nigrum & 2 & 0 & 50 & 0 & 0 & 50 \\
\hline 2 & Cardamom & $\begin{array}{c}\text { Elettaria } \\
\text { cardamomum }\end{array}$ & 8 & 13 & $0(2)$ & 13 & 13 & 13 \\
\hline 3 & Chilli pepper & $\begin{array}{c}\text { Capsicum } \\
\text { апnиит }\end{array}$ & 8 & 75 & $0(2)$ & 75 & 88 & 88 \\
\hline 4 & Coconut & Cocos nucifera & 8 & 100 & 75 & 75 & 88 & 75 \\
\hline 5 & Coriander & $\begin{array}{l}\text { Coriandrum } \\
\text { sativum }\end{array}$ & 8 & 88 & 100 & 100 & 100 & 88 \\
\hline 6 & Curry leaves & $\begin{array}{c}\text { Murraya } \\
\text { koenigii }\end{array}$ & 8 & 88 & $0(2)$ & 88 & 100 & 75 \\
\hline 7 & $\begin{array}{l}\text { Dry chilli } \\
\text { pepper }\end{array}$ & $\begin{array}{l}\text { Capsicum } \\
\text { annuum }\end{array}$ & 2 & 0 & 0 & 0 & 0 & 50 \\
\hline 8 & Grapes & Vitis vinifera & 7 & 43 & 29 & 14 & 14 & 29 \\
\hline 9 & Honey & Honey & 1 & 0 & 0 & 0 & 0 & 0 \\
\hline 10 & Kasuri methi & $\begin{array}{c}\text { Trigonella } \\
\text { foenum }\end{array}$ & 2 & 0 & 0 & 0 & 0 & 50 \\
\hline 11 & Mint & Mentha & 8 & 50 & 100 & 100 & 100 & 100 \\
\hline 12 & $\begin{array}{l}\text { Nuts and dry } \\
\text { fruits } \\
\text { (Almonds, } \\
\text { Cashew nuts, } \\
\text { Dry fig, Dry } \\
\text { grapes) }\end{array}$ & $\begin{array}{l}\text { (Prunus dulcis, } \\
\text { Anacardium } \\
\text { occidentale, } \\
\text { Ficus carica, } \\
\text { Raisins) }\end{array}$ & 8 & 63 & $0(2)$ & 0 & 25 & 50 \\
\hline 13 & Onion & Allium сера & 8 & 25 & $\begin{array}{l}50 \\
(2) \\
\end{array}$ & 50 & 25 & 25 \\
\hline 14 & Pomegranate & $\begin{array}{c}\text { Punica } \\
\text { granatum }\end{array}$ & 7 & 86 & $0(1)$ & 57 & 86 & 100 \\
\hline 15 & Spring onion & $\begin{array}{c}\text { Allium } \\
\text { fistulosum }\end{array}$ & 8 & 38 & $\begin{array}{l}100 \\
(2)\end{array}$ & 50 & 63 & 50 \\
\hline 16 & Tomato & $\begin{array}{c}\text { Solanum } \\
\text { lycopersicum }\end{array}$ & 7 & 86 & $\begin{array}{l}100 \\
(1)\end{array}$ & 100 & 29 & 71 \\
\hline
\end{tabular}

() indicates the number of samples used for the indicated garnish sample on the indicated medium. 
Table.2 Characterization of isolated bacteria

\begin{tabular}{|c|c|c|c|c|c|c|c|c|c|c|c|c|c|}
\hline $\begin{array}{c}\text { Isolated } \\
\text { Bacterium }\end{array}$ & Source & 预 & $\frac{0}{\tilde{\pi}}$ & 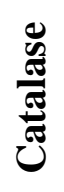 & 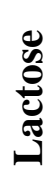 & $\frac{0}{\frac{0}{e}}$ & ن & 8 & 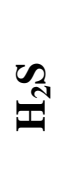 & 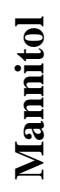 & $\underset{\mathscr{e}}{\mathscr{U}}$ & 莺 & 实 \\
\hline Citrobacter diversus & $\mathrm{C}, \mathrm{M}$ & - rods & - & & + & + & + & - & & & & & \\
\hline Escherichia coli & $\mathrm{C}, \mathrm{O}, \mathrm{S}, \mathrm{T}, \mathrm{Cu}$ & - rods & - & & + & + & - & & & & & & \\
\hline Klebsiella oxytoca & $\mathrm{P}, \mathrm{Gc}$ & - rods & - & & + & + & + & + & - & & & & \\
\hline Micrococcus varians & $\mathrm{N}$ & + cocci & & + & & & & & & - & + & & \\
\hline Pseudomonas & $\mathrm{Cu}$ & - rods & + & & & & & & & & - & & \\
\hline Shigella & $\mathrm{G}$ & - rods & - & & - & & & & & & & - & \\
\hline Staphylococcus aureus & $\begin{array}{l}\mathrm{C}, \mathrm{Co}, \mathrm{M}, \mathrm{G}, \\
\mathrm{S}, \mathrm{T}, \mathrm{Cu}, \mathrm{Gc}\end{array}$ & $+\operatorname{cocci}$ & & + & & & & & & + & & & \\
\hline Vibrio & $\begin{array}{c}\mathrm{C}, \mathrm{O}, \mathrm{S}, \mathrm{T}, \mathrm{Cu}, \\
\mathrm{Gc}, \mathrm{Ca}\end{array}$ & - rods & + & & & & & & & & + & & + \\
\hline
\end{tabular}

(Ca - Cardamom, C - Coconut, Co - Coriander, $\mathrm{Cu}$ - Curry leaves, G - Grapes, Gc - Green chilli, M - Mint, N -

Nuts and dry fruits, $\mathrm{O}-$ Onion, $\mathrm{P}-$ Pomegranate, $\mathrm{S}-$ Spring onion, $\mathrm{T}$ - Tomato)

Table.3 Antibiotic sensitivity test of isolated bacteria from food garnishes against the indicated antibiotics along with zone of inhibition in diameter $(\mathrm{mm})$

\begin{tabular}{|c|c|c|c|c|c|c|c|c|}
\hline Isolated Bacterium & 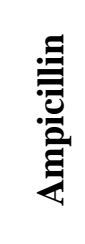 & 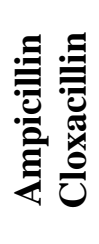 & 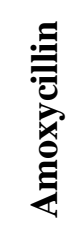 & 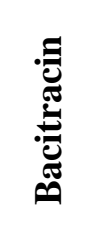 & 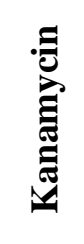 & 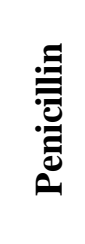 & 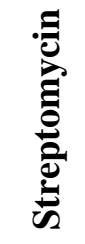 & 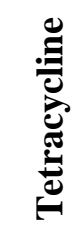 \\
\hline Citrobacter diversus & $\begin{array}{c}\mathrm{R} \\
(0) \\
\end{array}$ & $\begin{array}{c}\mathrm{R} \\
(0) \\
\end{array}$ & $\begin{array}{c}\mathrm{R} \\
(8) \\
\end{array}$ & $\begin{array}{c}\mathrm{R} \\
(0) \\
\end{array}$ & $\begin{array}{c}\mathrm{S} \\
(20) \\
\end{array}$ & $\begin{array}{c}\mathrm{R} \\
(19) \\
\end{array}$ & $\begin{array}{c}\mathrm{R} \\
(0) \\
\end{array}$ & $\begin{array}{c}\mathrm{S} \\
(31) \\
\end{array}$ \\
\hline Escherichia coli & $\begin{array}{c}\mathrm{S} \\
(17)\end{array}$ & $\begin{array}{c}\mathrm{R} \\
(16)\end{array}$ & $\begin{array}{c}\mathrm{R} \\
(19)\end{array}$ & $\begin{array}{c}\mathrm{R} \\
(0) \\
\end{array}$ & $\begin{array}{c}\mathrm{S} \\
(21)\end{array}$ & $\begin{array}{c}\mathrm{R} \\
(15) \\
\end{array}$ & $\begin{array}{c}S \\
(20) \\
\end{array}$ & $\begin{array}{c}\mathrm{R} \\
(11)\end{array}$ \\
\hline Klebsiella oxytoca & $\begin{array}{c}\mathrm{R} \\
(0)\end{array}$ & $\begin{array}{c}\mathrm{I} \\
(21)\end{array}$ & $\begin{array}{c}\mathrm{R} \\
(18)\end{array}$ & $\begin{array}{c}\mathrm{R} \\
(0)\end{array}$ & $\begin{array}{c}\mathrm{R} \\
(12)\end{array}$ & $\begin{array}{c}\mathrm{R} \\
(24)\end{array}$ & $\begin{array}{c}\mathrm{S} \\
(28)\end{array}$ & $\begin{array}{c}\mathrm{R} \\
(13)\end{array}$ \\
\hline Micrococcus varians & $\begin{array}{c}\mathrm{R} \\
(24)\end{array}$ & $\begin{array}{c}\mathrm{R} \\
(27)\end{array}$ & $\begin{array}{c}\mathrm{S} \\
(21)\end{array}$ & $\begin{array}{c}S \\
(15)\end{array}$ & $\begin{array}{c}\mathrm{R} \\
(12)\end{array}$ & $\begin{array}{c}\mathrm{R} \\
(12) \\
\end{array}$ & $\begin{array}{c}\mathrm{R} \\
(0)\end{array}$ & $\begin{array}{c}\mathrm{S} \\
(19)\end{array}$ \\
\hline Psuedomonas & $\begin{array}{c}\mathrm{R} \\
(10)\end{array}$ & $\begin{array}{c}\mathrm{R} \\
(10)\end{array}$ & $\begin{array}{c}\mathrm{R} \\
(11)\end{array}$ & $\begin{array}{c}\mathrm{R} \\
(0)\end{array}$ & $\begin{array}{c}\mathrm{S} \\
(19)\end{array}$ & $\begin{array}{c}\mathrm{R} \\
\text { (13) }\end{array}$ & $\begin{array}{c}\mathrm{S} \\
(21)\end{array}$ & $\begin{array}{c}\text { S } \\
(23)\end{array}$ \\
\hline Shigella & $\begin{array}{c}\mathrm{R} \\
(0)\end{array}$ & $\begin{array}{c}\mathrm{R} \\
(10)\end{array}$ & $\begin{array}{c}\mathrm{R} \\
(8)\end{array}$ & $\begin{array}{c}\mathrm{R} \\
(0)\end{array}$ & $\begin{array}{c}\mathrm{S} \\
(20)\end{array}$ & $\begin{array}{c}\mathrm{R} \\
(0)\end{array}$ & $\begin{array}{c}\mathrm{R} \\
(0)\end{array}$ & $\begin{array}{c}\mathrm{R} \\
(0)\end{array}$ \\
\hline Staphylococcus aureus & $\begin{array}{c} \\
(36)\end{array}$ & $\begin{array}{c}\mathrm{R} \\
(31)\end{array}$ & $\begin{array}{c}\mathrm{S} \\
(23)\end{array}$ & $\begin{array}{c}\mathrm{S} \\
(18)\end{array}$ & $\begin{array}{c}\mathrm{I} \\
(16)\end{array}$ & $\begin{array}{c}\mathrm{S} \\
(45)\end{array}$ & $\begin{array}{c}\mathrm{S} \\
(39)\end{array}$ & $\begin{array}{c}\mathrm{S} \\
(25)\end{array}$ \\
\hline Vibrio & $\begin{array}{c}\mathrm{R} \\
\text { (19) }\end{array}$ & $\begin{array}{c}\mathrm{S} \\
(22)\end{array}$ & $\begin{array}{c}\mathrm{S} \\
(24)\end{array}$ & $\begin{array}{c}\mathrm{R} \\
(0)\end{array}$ & $\begin{array}{c}\mathrm{R} \\
(0)\end{array}$ & $\begin{array}{c}\mathrm{R} \\
(17)\end{array}$ & $\begin{array}{c}\mathrm{S} \\
(22)\end{array}$ & $\begin{array}{c}\mathrm{R} \\
(0)\end{array}$ \\
\hline
\end{tabular}

(R: resistant, S: sensitive, I: intermediate) The inhibition zone size (diameter in $\mathrm{mm}$ ) interpretation was based on HiMedia instruction sheet (the following values are upper and lower cut-off lines for $\mathrm{R}$ and $\mathrm{S}$, respectively): 13 and 17 (for Enterobacteriaceae), and 28 and 29 (for others) for Ampicillin; 16 and 22 (for E.coli), and 35 and 37 (for S. aureus) for Ampicillin cloxacillin; 19 and 20 for Amoxycillin; 8 and 13 for Bacitracin; 13 and 18 for Kanamycin; 26 and 47 (for Enterobacteriaceae), and 19 and 28 (for others) for Penicillin; 11 and 15 for Streptomycin; 14 and 19 for Tetracycline (Banerjee, 2003) 
Table.4 Decontaminant test of isolated bacteria from food garnishes against the indicated decontaminants along with zone of inhibition in diameter $(\mathrm{mm})$

\begin{tabular}{|c|c|c|c|c|c|c|c|c|}
\hline Isolated Bacterium & 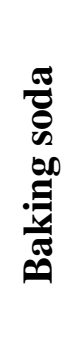 & 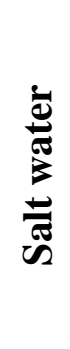 & 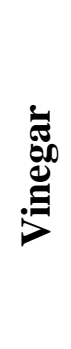 & 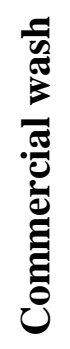 & 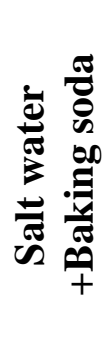 & 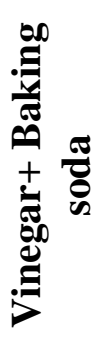 & 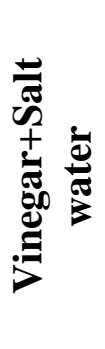 & 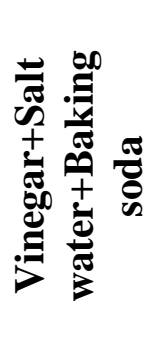 \\
\hline Citrobacter diversus & 0.7 & 0.8 & 1 & 1.1 & 0 & 1.1 & 1.1 & 0.8 \\
\hline Escherichia coli & 0 & 0 & 1.1 & 0 & 0 & 1.3 & 1.1 & 0 \\
\hline Klebsiella oxytoca & 0 & 0.8 & 1 & 0 & 0 & 0 & 0 & 0 \\
\hline Micrococcus varians & 0 & 0 & 1.1 & 0.8 & 0 & 1 & 1.1 & 0 \\
\hline Pseudomonas & 0 & 0 & 0.7 & 0 & 0 & 0 & 1.2 & 0 \\
\hline Shigella & 0 & 0 & 0.8 & 0 & 0 & 0 & 0.7 & 0 \\
\hline Staphylococcus aureus & 0 & 0 & 1.3 & 0 & 0 & 0 & 1.4 & 0 \\
\hline Vibrio & 0 & 0 & 1.1 & 0 & 0 & 0 & 1.2 & 0 \\
\hline
\end{tabular}

Figure.1 Distribution of positive isolates from indicated food garnishes on respective medium.

* indicates samples that were eliminated from analyses following the initial screening

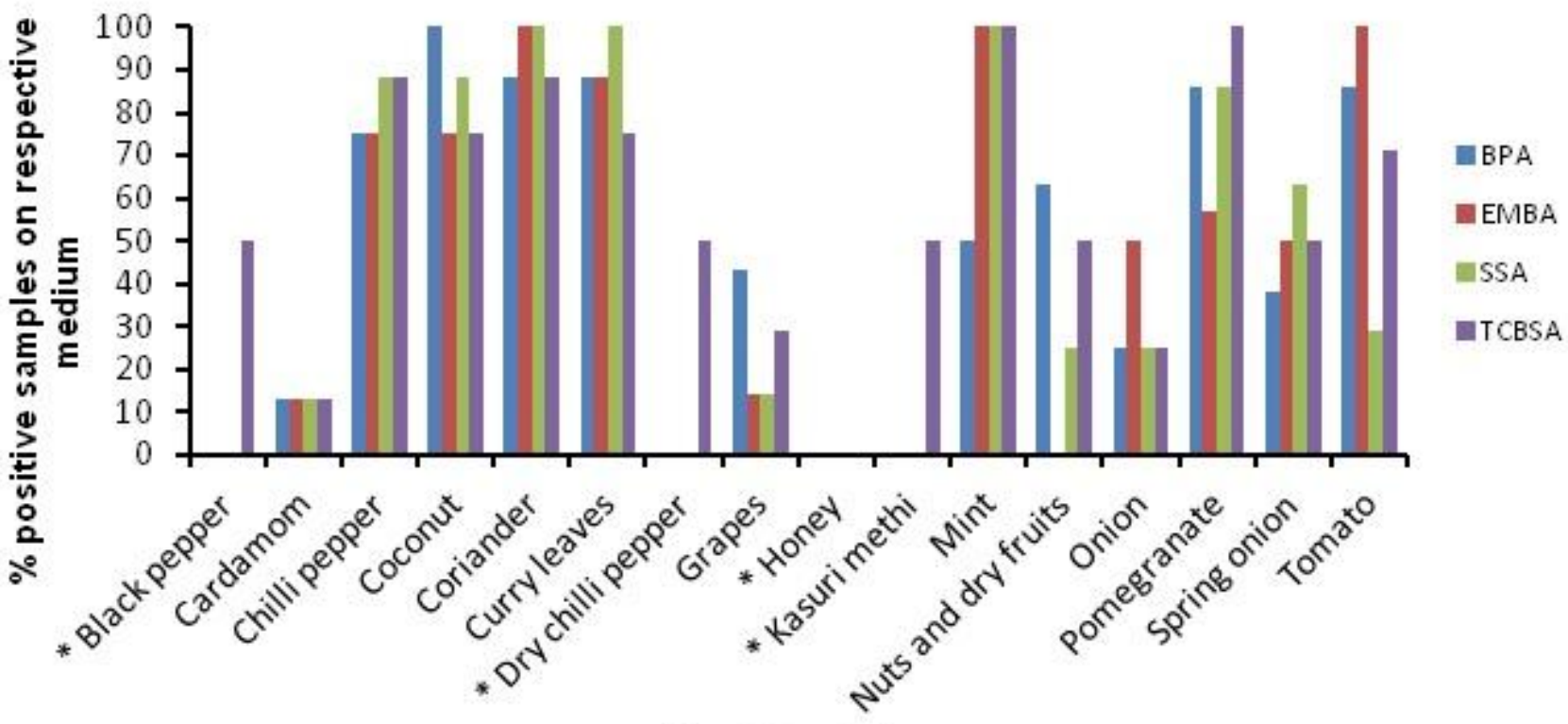

Food Garnishes 
Figure.2 Graphs (A-H) showing the zones of inhibition for indicated bacterium against indicated antibiotics. Red data labels indicate antibiotic resistance to the particular antibiotic. (Antibiotics: Amp - Ampicillin, Amp Cx - Ampicillin Cloxacillin, Amox - Amoxycillin, Bac - Bacitracin, Kan - Kanamycin, Pen - Penicillin, Strep - Streptomycin, Tetra - Tetracycline)
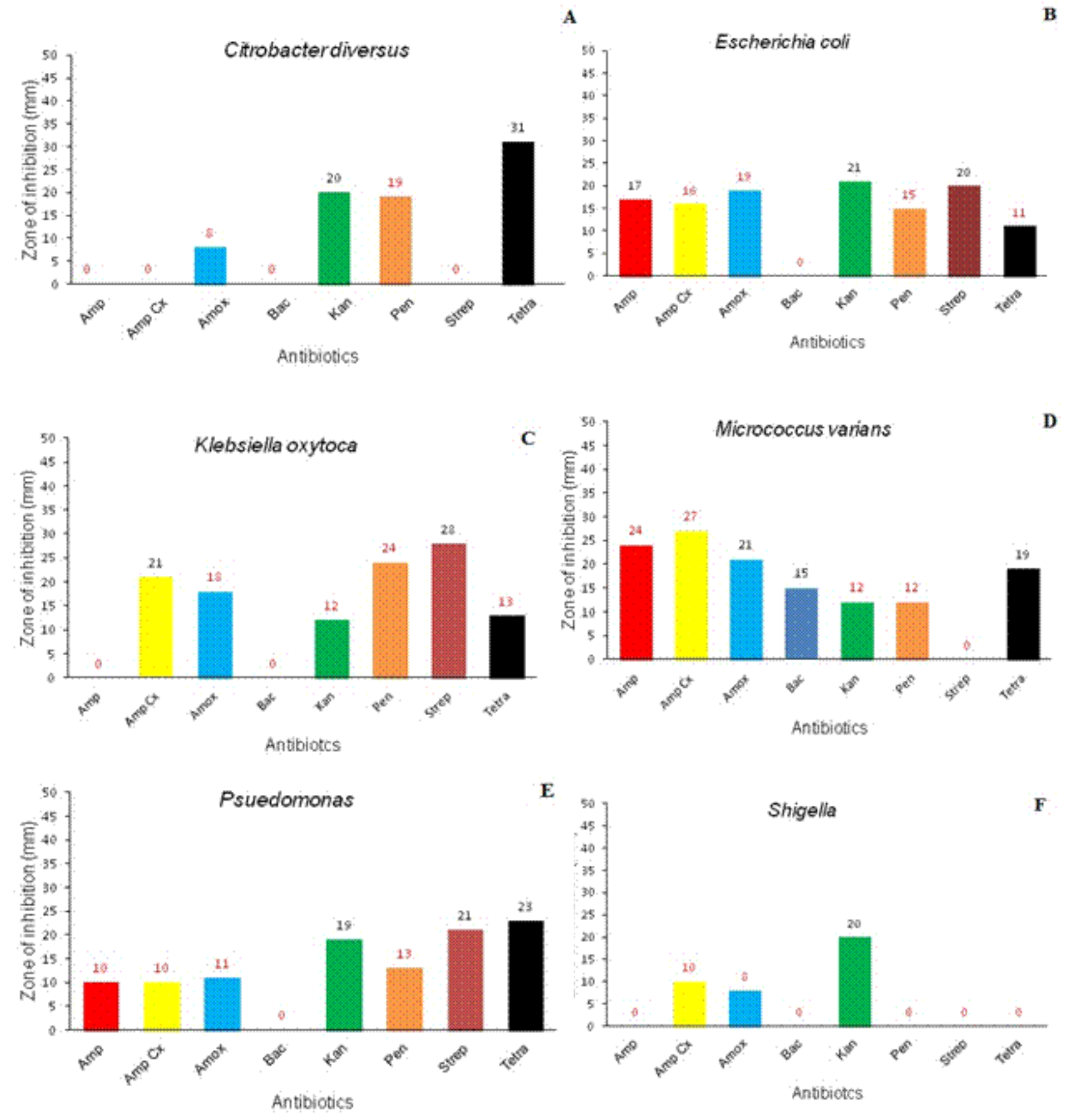


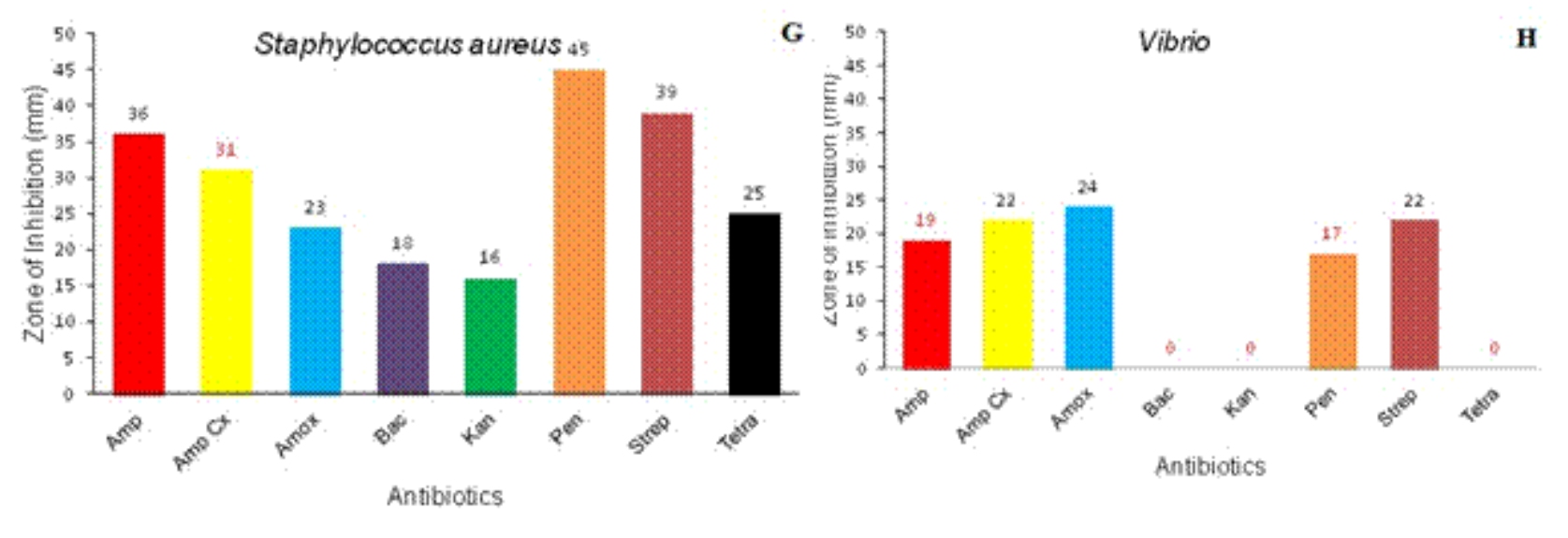

Figure.3 Graphs (A-H) showing the zones of inhibition for indicated bacterium against indicated decontaminants. (BS- baking soda, SW- salt water, V- vinegar, CFVW- commercial fruit and vegetable wash)
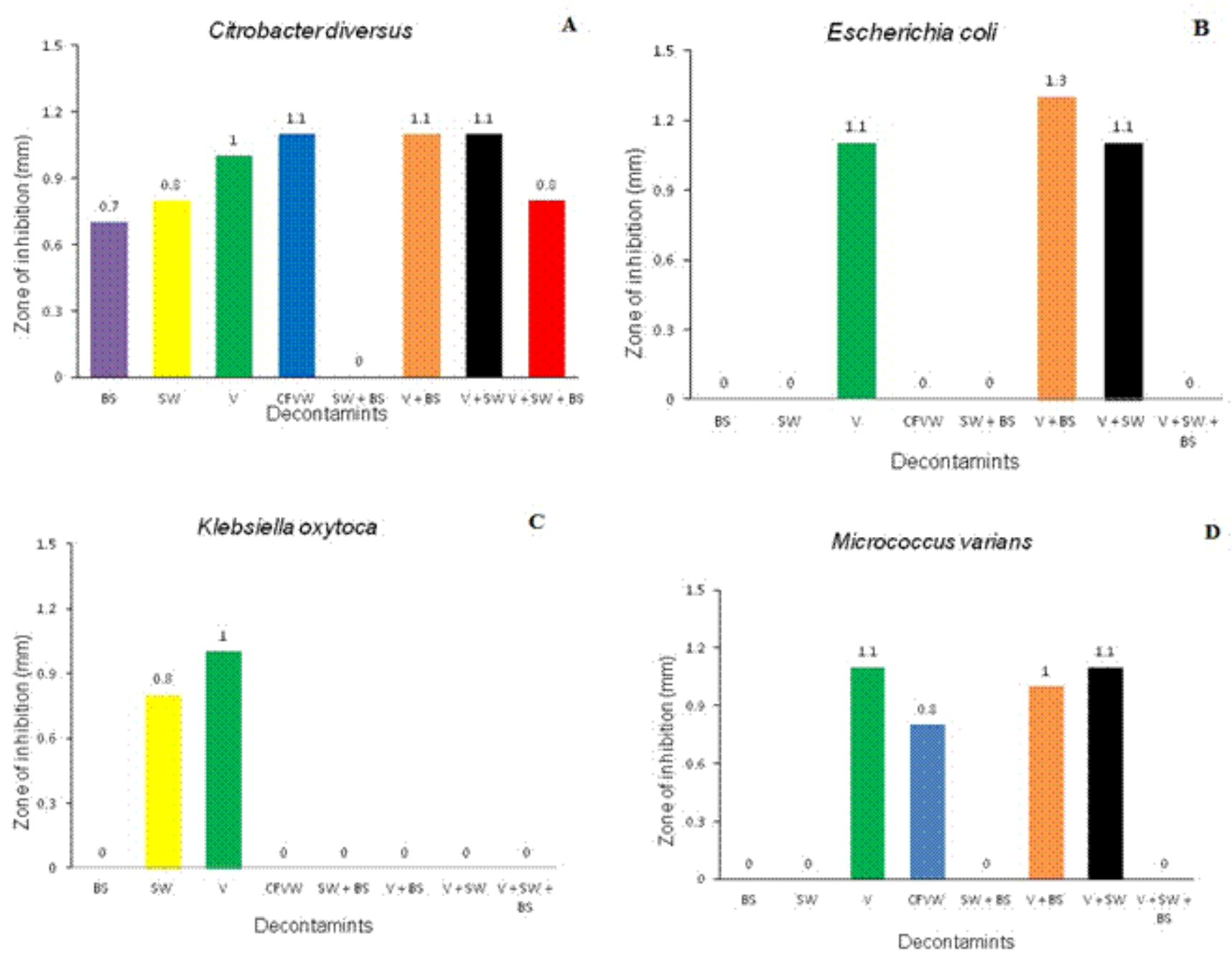

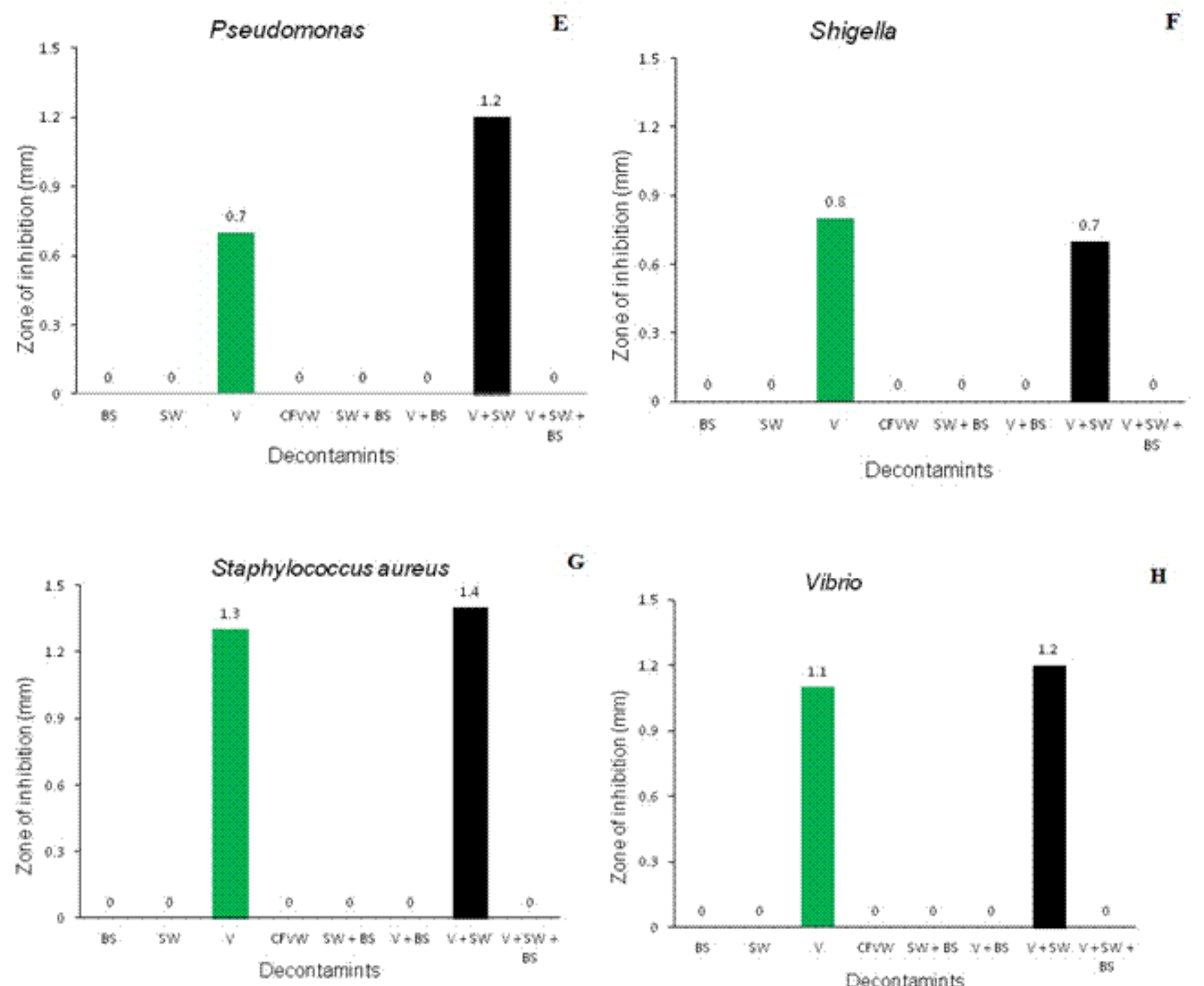

G

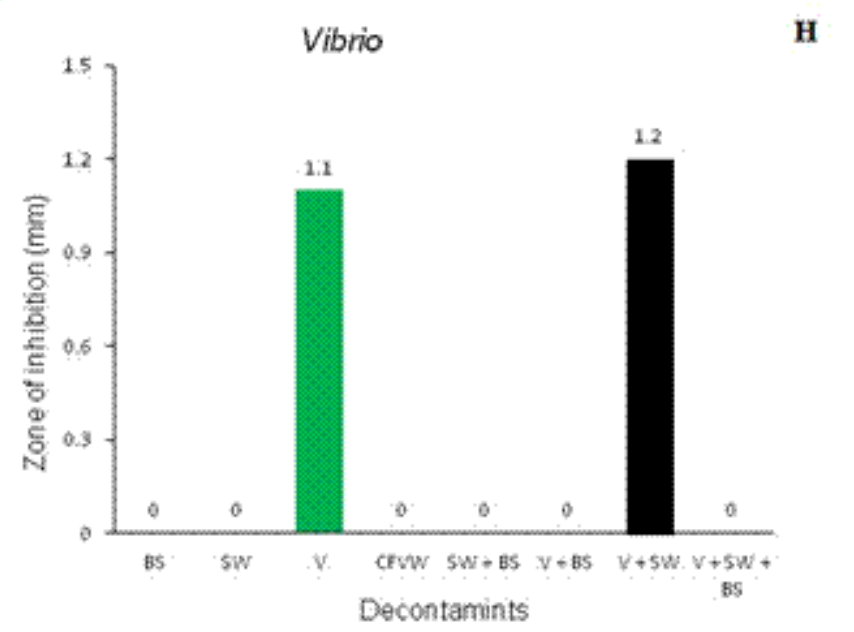

The commercially available fruit and vegetable wash was only found to be effective against $M$. varians. Only vinegar and 5\% salt in vinegar were found to be effective against Pseudomonas, Shigella, Staphylococcus aureus and Vibrio. Hence, vinegar and 5\% salt in vinegar were found to be the most effective against the isolated bacteria from food garnishes. These results agree with the observed antimicrobial activity of vinegar (Frederick, 1994; Lingham, 2012) and can now be said to be useful for food garnishes as well. Since both vinegar and salt are consumable items, it can be safely recommended to use these for washing food garnishes before application on to food items.
However, scope for optimization of these decontaminants still exist.

Addition of $5 \%$ salt to the vinegar did not have any additional effect on the zones of inhibition. Interestingly, addition of $5 \%$ baking soda to vinegar did affect the antibacterial action of vinegar on few isolates. These behaviors need to be investigated in future in order to optimize the use of the decontaminants. The present study was a qualitative one wherein the presence of a zone of inhibition was analyzed as a possibility that the tested substance or combination of substances would act as a decontaminant. Further studies using these decontaminants by 
measuring their minimum inhibitory concentrations and by analyzing their potential in reducing the microbial load would further corroborate their role as effective decontaminants.

In conclusion, we have shown that food garnishes harbour a wide variety of potentially pathogenic and/or food spoilage causing bacteria. These bacteria are generally resistant to multiple antibiotics. As food garnishes are mostly used in an uncooked form, chances of food spoilage and foodborne infection is very high. Therefore, instead of relying on antibiotic treatment following an infection, home remedies can be used for washing food garnishes before application on to food items, thus, reducing such chances of food spoilage and food-borne infection.

\section{Acknowledgement}

This work was supported by the Gokula Education Foundation and Department of Microbiology, Ramaiah College of Arts, Science and Commerce.

\section{References}

Adams, M.R., and Moss, M.O. 2000. Food Microbiology. New Age International (P) Ltd, Publishers. (ISBN: 8122410146, 9788122410143).

Alanis, A.J. 2005. Resistance to Antibiotics: Are We in the Post-Antibiotic Era? Archives of Med. Res., 36(6): 697 - 705.

Ali, A., Haider, M.S., Hanif, S., and Muhammad, A. 2014. Bacterial Diversity in some selected Agricultural Food Products. J. Bot., 43(2): 219-222.

Andleeb, S., Warsi, I.M., Malik, K., and Shahnawaz, K. 2013. Drug resistance of coliforms isolated from mint collected from market and home gardens. Punjab Univ. J. Zool., 28(1): 0001-0006.

Arslan, S., Eyi, A., Özdemir, F. 2011. Spoilage potentials and antimicrobial resistance of
Pseudomonas spp. isolated from cheeses. J. Dairy Sci., 94(12): 5851-5856.

Banerjee, M., and Sarkar, P.K. 2003. Microbiological quality of some retail spices in India. Food Res. Int., 36(5): 469-474.

Banerjee, M., and Sarkar, P.K. 2004. Antibiotic resistance and susceptibility to some food preservative measures of spoilage and pathogenic micro-organisms from spices. Food Microbiol., 21: 335-342.

Bergey's Manual of Systematic Bacteriology, 2nd edition. 2012. Springer-Verlag, New York, NY.

Bowles, B.L., and Juneja, V.K. 1998. Inhibition of food-borne bacterial pathogens by naturally occurring food additives. $J$. Food Safety, 18: 101-112.

Bowles, B.L., Sackitey, S.K., and Williams, A.C. 1995. Inhibitory effects of flavor compounds on Staphylococcus aureus WRRC B124. J. Food Safety, 15: 337347.

Bradley, E.M., Williams, J.B., Schilling, M.W., Coggin, P.C., Crist, C., Yoder, S., and Campano, S.G. 2011. Effects of sodium lactate and acetic acid derivatives on the quality and sensory characteristics of hotboned pork sausage patties. Meat Sci., 88: 145-150.

Campbell, J.V., Mohle-Boetani, J., Reporter, R., Abbott, S., Farrar, J., Brandl, M., Mandrell, R., and Werner, S.B. 2001. An Outbreak of Salmonella Serotype Thompson Associated with Fresh Cilantro. J. Infect. Dis., 183 (6): 984-987.

Chantaysakorn, P., and Richter, R.L. 2000. Antimicrobial properties of Pepsindigested Lactoferrin added to carrot juice and filtrates of carrot juice. J. Food Prot., 63(3): 376-380.

Clarridge III, J.E. 2004. Impact of 16S rRNA Gene Sequence Analysis for Identification of Bacteria on Clinical Microbiology and Infectious Diseases. G. Clin. Microbiol. Rev., 17(4): 840-862.

Delaquis, P.J., and Mazza, G. 1995. Antimicrobial properties of isothiocyanates in food preservation. 
Food Technol., 49(11): 73-84.

Doran, T.I. 1999. The role of Citrobacter in clinical disease of children: review. Clin. Inft. Dis., 28(2): 384-394.

Drake, S.L., DePaola, A., and Jaykus, L.A., 2007. An overview of Vibrio vulnificus and Vibrio parahaemolyticus. Compr. Rev. Food Sci. Food Saf., 6: 120-144.

Elviss, N.C., Little, C.L., Hucklesby, L., Sagoo, S., Surman-Lee, S., de Pinna, E., and Threlfall, E.J. 2009. Microbiological study of fresh herbs from retail premises uncovers an international outbreak of Salmonellosis. Int. J. Food microbial., 134 (1-2): 83-88.

Frederick, T.L., Miller, M.F., Thompson, L.D., and Ramsey, C.B. 1994. Microbiological properties of pork cheek meat as affected by acetic acid and temperature. J. Food Sci., 59: 300-305.

Frost, J.A., McEvoy, M.B., Bentley, C.A., Andersson, Y., and Rowe, B. 1995. An outbreak of Shigella sonnei infection associated with consumption of iceberg lettuce. Emerging Infectious Dis., 1: 2629.

Fukao, T., Sawada, H., and Ohta, Y. 2000. Combined effect of hop resins and sodium hexametaphosphate against certain strains of Escherichia coli. J. Food Prot., 63: 735-740.

Ghosh, M., Wahi, S., Kumar, M., and Ganguli, A. 2007. Prevalence of enterotoxigenic Staphylococcus aureus and Shigella spp. in some raw street vended Indian foods. Int. J. Environ. Health Res., 17(2): 151156.

Hsu, W.Y., Simonne, A., Jitareerat, P., and Marshall, M.R. Jr. 2010. Low-dose irradiation improves microbial quality and shelf life of fresh mint (Mentha piperita L.) without compromising visual quality. J. Food Sci., 75(4): M222-230.

Israili, Z.H. 2014. Antimicrobial properties of honey. Am. J. Ther., 21(4): 304-323.

Kang, C.I., and Song, J.H. 2013. Antimicrobial resistance in Asia: current epidemiology and clinical implications. Infect. Chemother., 45: 22-31.
Keskin, D., and Toroglu, S. 2011. Studies on antimicrobial activities of solvent extracts of different spices. B. J. Environ. Biol., 32(2): 251-256.

Khan, M.R., Saha, M.L., and Khan, F.I. 2012. Bacteria Associated with Common Spices and Their Possible Implications. Int. J. Microbiol. Res., 3(1): 53-58.

Lynch, F.T. 1987. Garnishing: A Feast for Your Eyes. (ISBN-10: 0895864762 ISBN13: 978-0895864765).

Lingham, T., Besong, S., Ozbay, G., and Lee, J. 2012. Antimicrobial Activity of Vinegar on Bacterial Species Isolated from Retail and Local Channel Catfish. J. Food Process Technol., S11-001.

Lund, B. M. 1993. The microbiological safety of prepared salad vegetables. Food Technol. Int. Europe, 3: 196-200.

Naimi, T.S., Wicklund, J.H., Olsen, S.J., Krause, G., Wells, J.G., Bartkus, J.M., Boxrud, D.J., Sullivan, M., Kassenborg, H., Besser, J.M., Mintz, E.D., Osterholm, M.T., and Hedberg, C.W. 2003. Concurrent outbreaks of Shigella sonnei and enterotoxigenic Escherichia coli infections associated with parsley: implications for surveillance and control of foodborne illness. J. Food Prot., 66(4): 535-541.

Nipa, M.N., Mazumdar, R.M., Hasan, M.M., Fakruddin, M., Islam, S., Bhuiyan, H.R., and Iqbal, A. 2011 Jan. Prevalence of Multi Drug Resistant Bacteria on Raw Salad Vegetables Sold in Major Markets of Chittagong City, Bangladesh. MiddleEast J. Scientific Res., 10(1): 70-77.

Reddy, S.V., Srinivas, P.V., Praveen, B., Kishore, K.H., Raju, B.C., Murthy, U.S., and Rao, J.M. 2004. Antibacterial constituents from the berries of Piper nigrum. Phytomed., 11(7-8): 697-700.

Roy, A., Moktan, B., and Sarkar, P.K. 2007. Characteristics of Bacillus cereus isolates from legume-based Indian fermented foods. Food Control, 18(12): 1555-1564.

Sabota, J.M., Hoppes, W.L., Ziegler, J.R., DuPont, H., Mathewson, J., Rutecki, G.W. 1998. A new variant of food 
poisoning, enteroinvasive Klebsiella pneumoniae and Escherichia coli sepsis from a contaminated hamburger. Am. J. Gastroenterol., 93(1): 118-119

Sago, S.K., Little, C.L., Ward, L., Gillespie, I.A., Mitchel, T.L. 2003. Microbiological study of ready-to-eat salad vegetables from retail establishments uncovers a national outbreak of salmonellosis. $J$. Food Protection, 66(3): 403-409.

Schaffner, C.P., Mosbach, K., Bibit, V.C., and Colin, H. 1967. Coconut and Salmonella Infection. Appl. Microbiol., 15(3): 471-5.

Shrivastava, S. 2014. Bacteriological analysis of Fresh vegetables and Fruits of local market and effect of Pretreatment by Antimicrobial agents on their Quality. Int. Res. J. Biol. Sci., 3(11): 15-17.

Silbernagel, K.M., and Lindberg, K.G. 2001. Petrifilm rapid S. aureus Count Plate method for rapid enumeration of Staphylococcus aureus in selected foods: collaborative study. J. AOAC Int., 84: 1431-1443.

Tokuoka, K., and Isshiki, K. 1994. Possibility of application of Allylisothiocyanate vapor for food preservation. Nippon Shokuhin Kogyo Gakkaishi, 41(9): 595599.

Tzortzakis, N.G. 2010. Ethanol, vinegar, and origanum vulgare oil vaprour suppress the development of anthracnose rot in tomato fruit. Int. J. Food Microbiol., 142: 14-18.

WHO. 2001. Drug resistance. Global strategy for containment of antimicrobial resistance. Geneva: World Health Organization.

Wogu, M.D., and Ofuase, O. 2014. Microorganisms responsible for the spoilage of tomato fruits, Lycopersicum esculentum, sold in markets in Benin City, southern Nigeria. Sch. Acad. J. Biosci., 2(7): 459-466.

Wu, F.M., Doyle, M.P., Beuchat, L.R., Wells, J.G., Mintz, E.D., and Swaminathan, B. 2000. Fate of Shigella sonnei on parsley and methods of disinfection. J. Food Prot., 63(5): 568-572.

Yadav, U.C., and Baquer, N.Z. 2014. Pharmacological effects of Trigonella foenum-graecum L. in health and disease. D. Pharm Biol., 52(2): 243-254.

Zhuang R. Y., Beuchat, L.R., and Angulo, F.J. 1995. Fate of Salmonella montevideo on and in raw tomatoes as affected by temperature and treatment with chlorine. Appl. Environ. Microbiol., 61(6): 21272131.

\section{How to cite this article:}

Payel Sarkar, R. Divya, S. Sumanashree, and Swathi, K. 2017. Decontamination Strategies for a Few Potentially Pathogenic and Food Spoilage Causing, Antibiotic-Resistant Bacteria Isolated From Commonly Used Food Garnishes. Int.J.Curr.Microbiol.App.Sci. 6(2): 12351248. doi: http://dx.doi.org/10.20546/ijcmas.2017.602.140 